\title{
THE CALL TO HOLINESS: THE EFFECT OF UNDERSTANDING CONCEPT OF SECOND COMING AT GPdI RAJAWALI'S YOUTH SURABAYA
}

\author{
Nina Astrid Karina \\ Evangelical Theological Seminary of Indonesia - Surabaya \\ E-mail: ninaastridkarina@gmail.com
}

\begin{abstract}
Holiness is the condition, means and purpose for all believers that distinguishes them as God's people. In contrast to the condition of the world which is increasingly immersed in sin, the holiness of the believer will continue to progress until it reaches perfection. Starting from believing until finally when Christ comes the second time. This research was conducted to prove that the understanding of the concept of the second coming of Christ affects the holiness of the GPdI Rajawali Surabaya's youth. From the quantitative research that has been done, it is evident that understanding this concept has a positive effect in the moderate category.
\end{abstract}

Keywords: Quantitative, Eschatology, Second Coming, Sanctification, Holiness

\section{INTRODUCTION}

Holiness is a strange thing for most people today. Sin has become commonplace in all aspects of life. Through many advances from technology and easily accessible social media, everyone can see what the world is like today. What used to be done secretly because it was considered immoral or violated the prevailing rules and norms, now it becomes a source of pride for feeling brave, to be honest with one's condition. Then the news that is presented becomes an inspiration for others to do the same thing even more than that.

\section{The Background}

This condition is applied not only in the general public or unbelievers. Both the perpetrators and victims of this crime could be Christians. It has become a common thing, about young people who come to church, even the servants of God, many of them have a similar lifestyle with the world, even though they may not commit serious law violations. Whereas the Words of God clearly says in Leviticus 20:26 and 1 Peter 1:16, "Be holy, for I am holy."

The results of the discussion with the spiritual builder of the youth ministry commission at GPdI Rajawali also implied that the issue of the sanctity of youth lives needed to be considered more carefully in 
their involvement as part of God's church.

Even though physically, they took part in the ministry of God's work, however, their lifestyles and choices are often inconsistent with the truth of God's Word. This condition has fatal consequences because even though they are involved in ministry, they do not live in holiness.

Holiness is a condition of the believer's spirituality which is built from the understanding of God's Word. Believers do not live in holiness because they do not have an understanding of the true teachings of Christianity. The congregation prefers to hear the advice of God's Word which is practical but is reluctant to accept doctrinal teaching. For most Christians, doctrinal teaching is considered difficult to understand and boring. More Christians make spiritual leaders the standard of truth than the teaching of God's Word. Ideally, the entire congregation understands the various concepts or Christian doctrines in equal proportion. One of the basic teachings that must continue to be given to the Lord's church is teaching about the end times or eschatology.

This doctrine is important because all believers must have an eschatological hope, that is, Christ will come again for the second time to pick up His church. This is a distinctive, strong eschatological basis, and differentiates Christianity from other ideologies or religions. Eschatology or teaching about the end times is not a doctrine that Christians only have. Louis Berkhof stated that almost all religions on earth have their respective eschatological concepts. However, in these religions, things are still vague and uncertain. Only Christianity has clear teachings about the end times. This is what must be understood by the Lord's congregation, including the youth. If the understanding of the eschatology concept of the congregation is ambiguous and the same as that understood by non-Christians, then it is not surprising that their lifestyle and behavior are not much different from theirs.

This understanding is expected to be able to prevent them from moral behavior that deviates from the teachings of the truth of God's Word, and on the contrary can build them into dynamic, creative, consistent, and militant believers in maintaining the holiness of life in today's world. Parents, spiritual leaders, and church communities cannot remain silent and allow this young generation to be swept away by the world system because of their ignorance. There needs to be some teaching action for them so that it can help them understand the concept of second coming correctly. Because if this situation continues, the church will lose the next holy generation. 


\section{THEORIES}

\section{Problem's Identification}

Some of the problems that are used as a limitation of this research are cases of the holiness of the lives of young adolescents which have a direct correlation with the understanding of the concept of the second coming, including youths who have been involved in ministry are not keeping their lives holy. It is not quite right to make youths become people who live recklessly.

Based on the identified problems, the problem formulations in this research are: is there an effect of understanding the concept of the Second Coming for the holiness of the GPdI Rajawali youth and how much is this.

This research has the objective to prove the influence of understanding the concept of the Second Coming on the holiness of GPdI Rajawali Surabaya youth and how much it is.

Hope this research can be used as a reference by the church in providing the concept of Second Coming to the congregation, especially youth. With this understanding the concept of hope of believers is a great and true impetus for youth in keeping their lives holy.
Generally, the discussion about the end of time makes almost everyone automatically have the perception of the end of this world, that is, the earth will be ravaged, crumble to dust, and end of everything including human existence. This is the most common and simple knowledge for all people. This kind of understanding of the end times is mostly perfunctory without being complemented by a broader and more comprehensive understanding of eschatology.

From some of the definitions, it can be concluded that Eschatology is the study of the end times based on the Bible which deals with the realization of all things about human life personally and the history of the world in the last days. From these definitions, it can be interpreted that Christianity has teaching built from the revelation of God through His Words, that there will be things that will happen at the last time in human life and world history in general.

Theologically, Christian eschatology has aspects of the reward and place provided for mankind after their death and resurrection, God's judgment on the wicked, the coming of Christ, and the declaration of God's authority in His kingdom. It can be said that eschatology describes a scheme or outline of various events in connection with 
the second coming as God's promise to all believers before His ascension into heaven. That eschatology includes biblical teachings on the existence after death but not of the resurrection, the resurrection and inauguration (inauguration) of the church, the Tribulation, the Second Coming, and the Millennial Kingdom. These are the fundamental elements that make up the doctrine of Christian eschatology, regardless of how the interpretation of the sequence of events occurs.

\section{Second Coming}

The hope of Christ's second coming is the most important aspect of New Testament eschatology - so important that the faith of believers is dominated by this hope. Although chronologically the interpretation of events before the coming of Christ is divided into several major schools, in general, all existing views emphasize their eschatological expectations of this event. Paul used the term Parousia technically several times to denote the Lord's return with the idea that it denotes Christ's coming as distinct from His coming when He became a human. Parousia is used specifically about the climax event that will occur later when Christ comes the second time as a sure and ultimate manifestation of His glory. The definition of the second coming of Christ which comes from several figures of various views confirms one commonality that there will be a time when Jesus Christ will come back to the world in a different state from His first coming, as a fulfillment of promises and His glorious expressions. It sets the eyes of believers to Christ's return and encourages them to always be ready for His coming. His coming will separate His saints from the ungodly who will experience the final judgment to receive eternal punishment from God for their rebellion.

GPdI teaching states that since humans fell into $\sin$, the end times have been in progress. The time and sequence of events that will occur at the end of time have been planned by God. Jesus explained to His disciples about the events that preceded His second coming. The book of Revelation records all the secrets of God about the second coming, from the events that took place before His second coming, at the time of His second coming, and after His second coming, especially in the form of events: The Opening of the Seven Seals of God, the Blasting of the Seventh Trumpets of God, the Outpouring of the Seven Bowls of God's Wrath. The three sequences are translated into three aspects of the event, namely, separation, exclusion, and rapture.

Separation in this context can be defined as the process of division that occurs in human beings in the world throughout the 
centuries based on the condition of faith into three different types of human beings (unbelievers, imperfect churches, and perfect churches). Separation is not a chronological stage or sequence because it occurs simultaneously from the emergence of Christianity. Abolition has the definition of the event of the perfect church escape from Antichrist power along with the omission of the imperfect church at the end of the great tribulation. The perfect church will be banished to the wilderness and preserved in God. The perfect church has the assurance of God's providence in terms of securing salvation from God both on earth (without experiencing Antichrist persecution in the last days of the Tribulation) and later in the time of judgment. This is because the perfect church is constantly persevering in keeping the Word of God fully and still living true to the Word of God. Besides, the perfect church also lives in the experience with the Holy Spirit who dwells in it. The rapture is a direct meeting between believers both raised from the dead in every century and the perfected church, with Christ at His second coming in space witnessed by all mankind. People who are resurrected at the time of the rapture are pious since the world was made and people who died in Christ include people who were martyred at the time of the Antichrist.

\section{Sanctification}

Sanctification tends to convey one's perception of things that are divine, perfect, clean, holy, undefiled, and sinless. Chastity is the first word that most people will imagine when they hear the word holy.

From several definitions, we get the sense that etymologically holiness is a separate condition or condition to be set apart for God. Thus everything holy has a separate and distinct condition which refers to uncleanness and sin. In the New Testament, the concept of holiness is not emphasized on external things that seem like in Old Testament times, but rather on the relationship with God who has an existence as the Most Holy. The concept of holiness is more on ethical emphasis, contrary to things that are defiled because everything related to God is holy. Everything related to God is separated from worldly and impurity so that it has the same qualities as God. Where God is present, there His holiness is present according to the standards that come from Himself.

\section{Holiness}

In Indonesia, the history of the development of Pentecostalism is a sect among Protestants which refers to efforts to purify life. This happened because the flow was born from the Holiness Movement 
which was founded by John Wesley, who is famous for his teaching: the Doctrine of Holiness (Sanctification). Wesley's theology emphasizes living a holy life in thought and deed so that the Holy Spirit can remain, thus producing joy and true peace. Thus, the concept of holiness according to Wesley is the result of a process of total surrender to the Holy Spirit in thoughts and actions that bring a person to experience with God which will determine the person worthy of final salvation. This concept is used as a doctrine in the majority of Pentecostal schools including the GPdI.

Repentance means that a person turns away from evil and turns his heart and will to God, submits to God's commandments and desires, and leaves sin that begins with a change of mind that leads to a change in his actions. The proof that a person has decided to accept Jesus Christ as his personal Savior is repentance.

Sanctification refers to the act of living in the dimension of the mind, feeling, and will of the believers which the Holy Spirit continues to work on, which can be seen as long as the believers are still alive in the world. Sanctification is a follow-up to repentance in which the believers does not only stop from sinning but can grow in the fullness of Christ.

Two phases of perfection can be experienced by believers, namely: (1).
Perfection now. The perfection of man today is not perfect without sin, but the perfection of a heart that is given up and offered to do God's will, a heart that is sincere and fully willing to follow God. It is this kind of perfection that can be attained in life today among believers. The perfection which is also now attainable is a mature level of spiritual growth which is assumed to have attained the highest goal of spiritual growth; (2). Perfection to come. If the Bible talks about perfection in the future, it is the perfection that will exist when the believers have met the Lord Jesus Christ directly after He came. This is the sinless perfection that perfected humans achieve. This perfection cannot be cultivated by humans. At this level of perfection, man cannot sin again.

The concept of holiness taught in the Pentecostal church conditions the believers to continue to be active in the process. There is no chance for the believers not to live in holiness if they want to arrive at the final salvation that has been initiated in faith in Christ. Each stage in the concept of holiness brings believers to experience real progressivity as a manifestation of God's presence in the lives of humans that $\mathrm{He}$ saves. 


\section{RESEARCH METHOD}

The holiness has become one of the main goals of Christianity in practice and has become an emphasis in the church's doctrinal teaching. Many servants of God emphasize the importance of living a holy life for believers, but rarely measure the level of holiness of the congregation by scientific means. In this way, the pastor has a reference in knowing the conditions and serving his congregation better. Pastors will be motivated to be more creative in providing basic doctrinal teachings that can be easily understood by the congregation, especially youth.

According to the types of quantitative methods available, this study uses the Survey Research Design method. It is called survey research because this research uses a direct population to become a representative sample to conclude using a questionnaire as data collectors. The population is the object were members of the Youth Commission of the Pentecostal Church in Indonesia, J1. Rajawali no. 92 Surabaya, as many as 81 people.

The independent variable is the Understanding of the Concept of the Second Coming which will be referred to as the $\mathrm{X}$ variable, while the dependent variable is the Holiness of the GPdI Rajawali Surabaya's Youth which will be referred to as the Y variable.
The research instrument was tested on $50 \mathrm{GPdI}$ youths scattered in several cities in East Java. Of the 30 instruments tested, the results have been tested for validity and reliability, so that there are 26 valid and reliable research instruments left.

\section{RESULTS AND DISCUSSION}
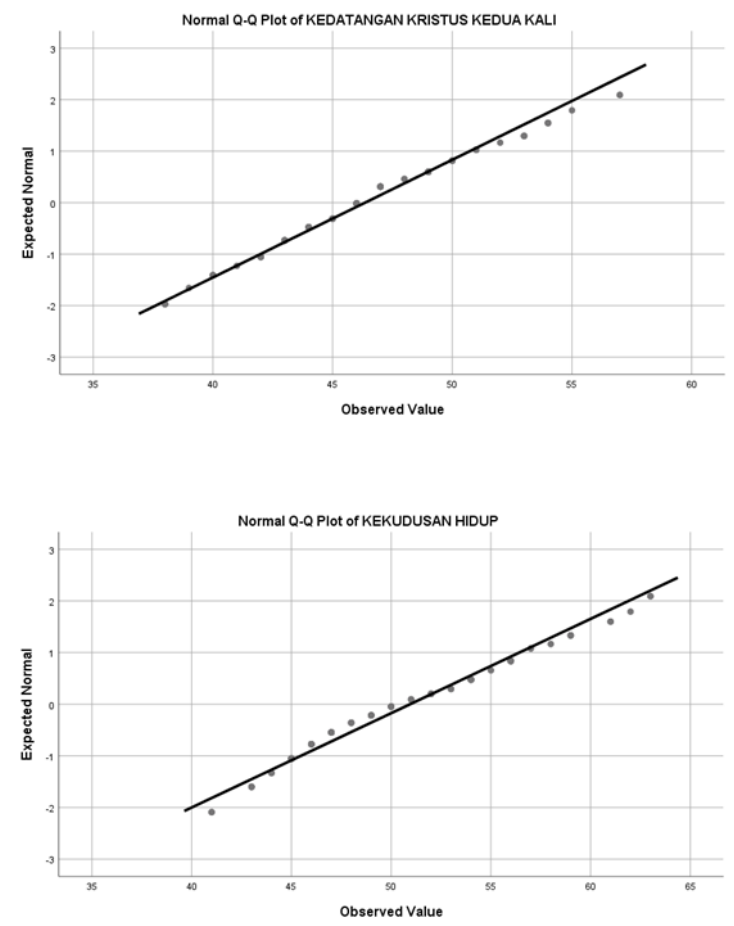

From the normality test guidelines with the Normal Q-Q Plots, by looking at the distribution of $\mathrm{X}$ and $\mathrm{Y}$ data above, it appears that these data have a normal distribution. Thus, the $\mathrm{X}$ variable and $\mathrm{Y}$ variable meet the distribution requirements with a normal distribution.

From the data description output, it can be seen that the significance value at Linearity is 0 . Because the significance is less than 0.05 , it can be concluded that the 
Understanding of the Concept of Second Coming and the Holiness of GPdI Rajawali Surabaya's Youth has a linear relationship. From the Deviation from Linearity value, it appears that Sig. $0.683>0.05$. This also shows that they have a linear relationship.

Thus, the two variables in this research have met the requirements of analysis testing so that the researcher can proceed to the next step, testing the hypothesis at the beginning of this research.

Based on the SPSS output, the Sig. is equal to 0.000 . Because of the Sig. $0.000<$ 0.05 , so according to the basis of decision making in the $\mathrm{F}$ test it can be concluded that the hypothesis is accepted or in other words the $\mathrm{X}$ variable simultaneously affects the $\mathrm{Y}$ variable. Meanwhile, it is known that the Significance (Sig) of the $\mathrm{X}$ variable is 0 . Because of the Sig. $0<$ probability 0.05 , it can be concluded that the hypothesis is accepted. This means that there is an influence of the $\mathrm{X}$ variable on the $\mathrm{Y}$ variable.

Both the $\mathrm{F}$ test and the t-test in this research clearly show that there is a significant influence on the $\mathrm{X}$ variable on the $\mathrm{Y}$ variable both partially and simultaneously. Thus, the conditions for calculating the correlation between the two variables have been fulfilled.

It is found that the R-value is 0.467 and is positive. Based on the guidelines for providing an interpretation of the correlation coefficient, the relationship between the variable is included in the moderate relationship category. The relationship between the two shows a positive direction.

Next, how strong the influence is can be seen from the results. The value of $\mathrm{R}^{2}$ (coefficient of determination) in this research was 0.218 or $21.8 \%$.

\section{CONCLUSION}

The main objective of this research is to prove the existence of influence as well as to measure how much influence the understanding of the concept of the Second Coming on the Holiness of Youth Life. Research data analysis has been completed and the initial hypothesis of the study has been proven. The Understanding of The Concept of Second Coming has a significant influence on the Holiness GPdI Rajawali Surabaya's Youth.

From the correlation test, The Understanding of The Concept of Second Coming has a significant influence on the Holiness GPdI Rajawali Surabaya's Youth. With the increasing understanding of this concept, the holiness of the life of the object of research will experience a moderate increase in size. The R2 value of this study is 0.218 , which means that the understanding of the concept of the Second 
Coming has contributed $21.8 \%$ to the Holiness of GPdI Rajawali Surabaya's Youth.

Other variables of $78.2 \%$ which affect the sanctity of the life of the research object are not included in this study and thus open up opportunities for further research.

\section{REFERENCES}

[1]. Arikunto, Suhaimi. Prosedur Penelitian Suatu Pendekatan Praktik. Jakarta: Rineka Cipta, 2006

[2]. Arikunto, Suhaimi. Manajemen Penelitian. Jakarta: Rineka Cipta, 2005

[3]. Baker, David L. Mari Mengenal Perjanjian Lama. Jakarta: BPK-GM, 2002

[4]. Baker, F.L. Sejarah Kerajaan Allah I. Jakarta: BPK-GM, 2007

[5]. Beeke, Joel R. The Beauty and Glory of Christ's Bride. Michigan: Grand Rapids, 2015

[6]. Berkhof, Louis. Teologi Sistematika 4: Doktrin Keselamatan. Surabaya: Momentum, 2012

[7]. Berkhof, Louis. Teologi Sistematika 6: Doktrin Akhir Jaman. Surabaya: Momentum, 1997
[8]. Bridges, Jerry. Mengejar Kekudusan.

Bandung: Pionir Jaya, 2009

[9]. Burns, Robert B. Introduction to Research Method, 4th Edition. French Forest NSW: Longman, 2000

[10]. Defour, Xaper Leon. Ensiklopedia Perjanjian Baru Jilid II. Yogyakarta: Kanisius.

[11]. Enns, Paul. The Moody Handbook of Theology. Malang: Seminari Alkitab Asia Tenggara, 2019

[12]. Erickson, Millard J. Introducing Christian Doctrine. US: Baker Academy, 2006

[13]. Erickson, Millard J. Pandangan Kontemporer dalam Eskatologi (Sebuah Studi tentang Milenium). Malang: Seminari Alkitab Asia Tenggara, 2000

[14]. Finlayson, R.A. dan J.D. Douglas, Kudus dalam Ensiklopedia Alkitab Jilid I. Jakarta: YKBK, 1992

[15]. Guthrie, Donald. Teologi Perjanjian Baru 3. Jakarta: BPK Gunung Mulia, 2016 [16]. Hoekema, Anthony A. Alkitab dan Akhir Zaman, Surabaya: Momentum, 2000 
[17]. Iskandar. Metodologi Penelitian

Pendidikan Sosial Kuantitatif dan

Kualitatif. Jakarta: Gaung Persada Press, 2009

[18]. Jaffray, R. A. Kristus Akan Datang

Untuk Yang Kedua Kalinya Bandung:

Kalam Hidup.

[19]. Lapian, L. dkk. Understanding Biblical Doctrine, Pangkalan Kerinci: Tiberias Publisher, 2018

[20]. Lindstom, Harald. Wesley and Sanctification: A Study in the Doctrine of Salvation Francis Asbury Press, 1998

[21]. Marantika, Chris. Doktrin Keselamatan dan Kehidupan Rohani, Yogyakarta: Iman Press, 2007

[22]. Marantika, Chris. Eskatologi Suatu Studi Tentang Nubuatan \& Hal-hal yang Akan Datang. Yogyakarta: Iman Press, 2007

[23]. Millard, Erickson J. Christian Theology 3, Malang: Gandum Mas, tt.

[24]. Minandar, J. S. Kedahsyatan Akhir Zaman, Dep. Penerbitan Literatur, Musik \& Kidung Gereja MP-GpdI

[25]. Priyanto, Dwi. Mandiri Belajar SPSS,
Yogyakarta: MediaKom, 2009

[26]. Priyanto, Dwi. Paham Analisis Statistika Data dengan SPSS. Yogyakarta: Media Kom, 2010

[27]. Ryrie, Charles C. Teologi Dasar 2. Yogyakarta: Penerbit ANDI, 1991

[28]. Sarmanu. Dasar Metode Penelitian Kuantitatif, Kualitatif dan Statistika. Surabaya: Airlangga Universitas Pres, 2017

[29]. Sasmoko. Metode Penelitian, Pengukuran dan Analisa Data. Tangerang: HITS, 2005

[30]. Sauter, Gerhard. What Dare We Hope? Rediscovery Eschatology. Harrisburg: Trinity Press, 1999

[31]. Susanto, Hasan. Konkordansi Perjanjian Baru Jilid II, Jakarta: LAI, 2003

[32]. Sproul, R.C. The Holiness of God, Batam: Gospel Press, 2002

[33]. Sugiono. Metode Penelitian Pendidikan Pendekatan Kuantitatif, Kualitatif, dan $R \& D$. Bandung: Alfabeta, 2010 
Journal Didaskalia

E-ISSN: 2621-8054

P-ISSN: 2622-1667

[34]. Sumanto. Teori dan Aplikasi Metode

Penelitian, Yogyakarta:FE UKRIM, 2017

[35]. Ridderbos, Herman. Paulus Pemikiran

Utama Teologinya, Surabaya: Momentum, 2015

[36]. Ryle, John Charles. Aspect of Holiness, London: Grace Publications Trust, 1999

[37]. Roberts, Roger. Hidup Suci: Panggilan bagi Setiap Orang Kristen, Bandung: Lembaga Literatur Baptis, 2000

[38]. Verkuyl, J. Aku Percaya, Jakarta: BPK Gunung Mulia, 2001

[39]. Wongso, Peter. Hermeneutika Eskatologi, Malang: Seminari Alkitab Asia Tenggara,1992

[40]. Yrigoyen, Charles Jr. John Wesley: Holiness of Heart and Life, Nashville: Abingdon Press, 1996 